\title{
Therapeutic Emesis (Vamana) - Management of Ekakustha - A Case Study
}

\author{
Case Study
}

\author{
Saurabh Deshmukh ${ }^{*}$, Bhagyashree Jibkate ${ }^{2}$, Ashish Zanwar ${ }^{3}$
}

1. Asst. Prof, Kayachikitsa, MGACH \& RC(H), Salod, Wardha, Maharashtra

2. JR1 Department of Rasa shastra \& Bhaisajya Kalpana, MGACH \& RC(H), Salod, Wardha, Maharashtra

3. Interne, MGACH \& RC(H), Salod, Wardha, Maharashtra

\begin{abstract}
50 years old male with well defined, slightly raised dry erythematous macules with silvery scales and typical extensor distribution diagnosed as ekkustha (psoriasis). As shodhan chikitsa is more effective patient is treated by giving sadhya snehan and madanphala vaman karma in which vitiated doshas are expelled through urdhvamarga. The patient vomited 6 times a total content of $3800 \mathrm{ml}$ against $2500 \mathrm{ml}$ of input. At the end of vaman, pitta is vomited. After an hour of vaman karma patient felt remarkable relief from itching, scaling and gradual reduction of erythema. The madanphala vaman karma (therapeutic emesis) is a safe Ayurveda .Panchakarma protocol to eliminate kapha accumulated either by pathological condition or dietetic mismanagement .
\end{abstract}

Keywords: Ekkushtha, Shodhan, Urdhwa Marga, Erythematous Macules, Vamana

\section{Introduction}

Kustha is described as one of the most chronic disorders (dirgha-roga) by Acharya Charak.(1) Among different types of Kustha ekakustha is described as one with symptoms like Aswedanam (Absence of perspiration.), Mahavasthuvam (present all over the body), Mastyasakalopamam (Skin resembles scales of fish) (2) All these symptoms can be co-related with psoriasis, in which silver fish scales is most predominant feature along with well circumscribed, sharply demarcated erythematous papules or plaques covered by dry, brittle, silvery or grayish white.

Acharyas has described Ekkustha as Raktapradosaj, Vatakaphapradhan Tridoshaj Kshudrakustha. (3) It bears a greater resemblance with psoriasis. The common initial site of occurrence of psoriasis such as scalp, knees \& earlobes \& other places of joints are also pertaining to the sthana of Vatadosha. Also there is limitations of available medications \& associated with side effects there is need to find out safe, long lasting \& better treatment for psoriasis. According to our classics Kustha being a Bahudoshavastha vyadhi repeated Shodhana is indicated. (4)

\section{Case Report}

The present case study is successful Ayurvedic management of a case of Ekakushtha (Plaque psoriasis). A 50 year old male patient with Registration

\footnotetext{
*Corresponding Author:

Saurabh Deshmukh

Asst. Prof, Kayachikitsa,

MGACH \& RC(H), Salod,

Wardha, Maharashtra

E-mail: ayurrulz@gmail.com
}

no 1603090038 came to MGACH \& RC with chief compliant of Plaque over both palm and sole with powdery discharge, Itching over palm \& sole (Kandu), Burning sensation over both sole (Daha), Discoloration on both palm \& sole (Vaivarnya) and associated symptom was- mild constipation since two year.

\section{History of present illness}

The patient was normal two year back. But Since then patient has been suffering from plaque over both palm and sole with powdery discharge, blackish spot and itching \& burning sensation over palm \& sole. Patient was also psychological upset since last 6 months. He had used various local and oral allopathic medicines. But there was no any significant relief. Even local use of soaps and creams were worsening the psoriasis. Hence he came to Mahatma Gandhi Ayurved College and Hospital for management.

\section{Past History- Not significant}

\section{Personal History:}

Occupation: Auto-driver.

Bad Habits: Chronic alcoholism, Tobacco Chewing.

$\mathrm{O} / \mathrm{E}$ :

- $\operatorname{Nadi}($ pulse $)=80 / \mathrm{min}$.

- Mala (stool) $=$ Vibandha

- Mutra (urine) $=$ Normal .

- Jeeva (tounge) $=$ Saam.

- Agni = Kshudhamandya

- Shabda $($ speech $)=$ Normal. S

- $\operatorname{parsha}($ skin $)=$ Khar, Raktawarniya

- Druka (eyes) = Normal.

- Akruti = Madhyama.

- Bala = Madhyama.

- $\operatorname{Raktadaaba}($ B.P) $=120 / 90 \mathrm{~mm} / \mathrm{Hg}$. 
Treatment plan- Patient was treated on OPD basis.

A) Selected Internal Ayurvedic Drugs-

Table no 1- Purva Karma - Agni Deepan (3gm twice a day) Snehapan with Panchatikta gugglu ghruta $\left(1^{\text {st }}\right.$ day $30 \mathrm{ml}$ with increasing order)

Duration: 03days for Agni deepan \& 6 days for Snehapan

\section{B) Selected external Ayurvedic Drugs-}

Drug: Snehan with Marichadi tail

Dose: Application one day before Vaman

The taila was applied on the whole body.

Duration: a day before vaman

C) Selected Internal Ayurvedic Drugs for vaman

Drugs- Dugdha (2500ml), Yashtimadhu Phanta (1000ml), Madanphala choorna (3gm),Vacha choorna $(5 \mathrm{gm})$ it is administered on the day of Vaman.

\section{Materials and Methods:}

Place of study- Mahatma Gandhi Ayurvedic College and Hospital, Wardha Maharashtra.

\section{Type of study}

Simple random single case study

\section{Selection of internal medicines}

Oral medications were selected on the basis of their properties useful in pacifying vitiated Dosha in Ekakushta and ability to relieve signs and symptoms of Ekakushta.

\section{Samprapti Ghatak}

Dosh : Tridosha

Dushya : Rasa, Rakta.

Adhishtana : Twaka.

\section{Plan for schedule}

In all types of kustha, snehapan is recommended at early stage. (5) Snehana is a purva karma that decides the whole outcome of shodhana. (6) The treatment plans as the sadhyasnehan along with sadhyavaman. Snehapana is given on the basis of agnideepana attained on that particular day of snehapan. Snehan enables body soft, provides snigdhatwa, and liquefies dosha \& increase kledata in the body. (7) Like this, it manages dosha \& helps in bringing them from shakha to kostha. Under the influence of adequate snehan, shodhan will be proper $\&$ there by restoration of dhatusamyata is achieved. (8)

Trikatu choorna (3 gm) was administered for deepana effect as mentioned as purvakamra before Vamana. After that the administration of medicine (panchatiktaguggulghruta) was started with an initial dose of $30 \mathrm{ml}$ at 6 A.M. on first day and goes on increasing to $60 \mathrm{ml}, 90 \mathrm{ml}, 120 \mathrm{ml}, 160 \mathrm{ml} \& 240 \mathrm{ml}$ for 6 days successively. Soon after snehapan, warm water is given in order to cleanse the mouth \& for proper digestion of sneha. Patient is advised not to sleep during day time $\&$ when he feels thirst warm water is given for drinking.
Next day onwards, the quantity of ghee is increased depending on agnibala \& pachanshakti of patient. The maximum quantity of consumed panchatiktaguggulghruta on last day is $240 \mathrm{ml}$. Patient is instructed to take hot water bath for 2 consecutive days to get mrudusweda. Since all the kusthas, sweda is contraindicated. (9)

\section{Vaman karma}

Seven days after snehapan, patient is subjected to undergo vaman karma. A day previous to vaman karma, the patient is instructed to take food that promotes production of Kapha like curd, mash, icecream \& milk diets which have the quality of kaphatklesha. (10)

After examining the pulse, blood pressure and respiration etc; on day of vaman karma during kaphakala i.e. 5 A.M. the patient is subjected to local abhyanga with marichadi tail and mrudusweda to chest \& back before starting the process. (11) The kapha toxins accumulated in the body are effectively removed by vaman, one of the five therapies of Panchakarma in Ayurveda. Vaman is therapeutic vomiting, which is medicated emesis therapy. A People with high imbalance of kapha are given this type of treatment, which looseness \& mobilize the toxins, in an effort to eliminate them from body. Waste products (vitiated doshas) are eliminated through the upper gastrointestinal tract i.e. through mouth. The objective of vaman therapy is to include vomiting in the person to get rid of mucus that causes excess kapha. Madanphala is said to be the best therapeutic emetic agent. Milk is used as a medium vamanpaga, (which facilitates the vaman.) (12)

\section{Vaman management}

After abhyang \& swedana (sudation), patient is asked to drink milk as much as he can consume. Patient consumed $2500 \mathrm{ml}$ of milk at first instance. After that vaman drug which contains madanphala churna (Randia dumetorum) 3gm, vacha churna (Acorus calamus) 5gm, saindhav (Rock salt) $5 \mathrm{gm}$ and honey $25 \mathrm{ml}$ is mixed together and administered with $50 \mathrm{ml}$ of milk.

After administering emetic drug waited for 15 minutes for self-induction of dosha elimination by vaman. This duration is for facilitating the dosha movement. The onset of perspiration on forehead indicates liquefaction of dosha \& horrification indicates that the dosha are dislodging from their seat of stagnation, abdominal distention indicates that the dosha have reached the stomach. This act is followed by nauseating $\&$ salivation that conforms the upward movement of dosha. At the end of procedure, it is observed that pittant vaman. Spontaneous vomiting was started within fifteen minutes. The proper Vaman symptoms were noted by observing the vomitus.

\section{Inference/observations:}

The Antiki, Vaigiki, Maniki, Laingiki purifications are as follows. 


\section{Procedural summary}

Measures

Mainiki (measurement) Input

$2500 \mathrm{ml}$

Output

Antiki (Procedural Inference)

Vegiki (No. of vomiting's)

Laingiki (Symptoms)

$3800 \mathrm{ml}$

6
Pittantik vaman

Kapha chadrika Present in vomitus $\&$ no bleeding was observed.

Patient given an output of $3800 \mathrm{ml}$ of content in 6 Vegas (emetics). Expresses the "madhyama shuddhi". (13) The entire process of vaman is completed in duration of 65 minutes. Patient felt relaxed, lightness in whole body, remarkable relief from itching \& gradual reduction of lesion as shown in figure 2 (compared to figure one of before treatment). As patient is selfexpressive of diminishing of emesis, dhumapana (therapeutic smoke inhalation) is given.

Grading- PASI (Psoriasis Area Severity Index)
Score (14)

Within each area, the severity is estimated by three clinical signs: Severity parameters are measured on a scale of 0 to 4 , from none to maximum. The body is divided into four sections (head $(\mathrm{H})(10 \%$ of a person's skin); arms (A) (20\%); trunk (T) (30\%); legs (L) $(40 \%))$. Each of these areas is scored by itself, and then the four scores are combined into the final PASI. For each section, the percent of area of skin involved, is estimated and then transformed into a grade from 0 to 6:

\begin{tabular}{|c|l|}
\hline $0 \% \quad$ of involved area & Grade: 0 \\
\hline$<10 \%$ of involved area & Grade: 1 \\
\hline $10-29 \%$ of involved area & Grade: 2 \\
\hline $30-49 \%$ of involved area & Grade: 3 \\
\hline $50-69 \%$ of involved area & Grade: 4 \\
\hline $70-89 \%$ of involved area & Grade: 5 \\
\hline $90-100 \%$ of involved area & Grade: 6 \\
\hline
\end{tabular}

Table no.1 $(15,16)$ Table showing Dose, Route, Kala and Anupan of purva karma drugs

\begin{tabular}{|l|l|l|l|l|l|}
\hline Sr No & Name Of Medicine & \multicolumn{1}{|c|}{ Dose } & Route & \multicolumn{1}{c|}{ Kala } & \multicolumn{1}{c|}{ Anupan } \\
\hline 1 & Trikatu churna & 3 gm twice a day & Oral & Before meal & Luke warm water \\
\hline 2 & Panchatiktaguggulghruta & $30 \mathrm{ml}-1^{\text {st }}$ day & Oral & Early morning at & Luke warm water \\
& & $60 \mathrm{ml}-2^{\text {td }}$ day & & 7 A.M & \\
& & $90 \mathrm{ml}-3^{\text {rd }}$ day & & & \\
& & $120 \mathrm{ml}-4^{\text {th day }}$ & & & \\
& & $160 \mathrm{ml}-5^{\text {th }}$ day & & & \\
\end{tabular}

Table no 2- (17) Showing ingredients of external preparations with their properties used in purva karma (Abhyanga \& swedana)

\begin{tabular}{|l|l|l|l|}
\hline Sr No & Name of Medicine & \multicolumn{1}{|c|}{ Ingredients } & \multicolumn{1}{|c|}{ Properties and use } \\
\hline 1 & Marichadi Tail & Krishna Marich, Haratala, Manshila, & Raktashodhak, Vranropak, \\
& & Musta, Arkadugdha, Ashwamara, & Twachya, useful in skin disease. \\
& & Jatamansi, Nishotha, Gomayarasa, & Dadru, shwitra, kushtha. \\
& & Indrayana, Kushta, Haridra,, & \\
& & Daruharidra, Gevadaru,Shwetachandan, Gomutra, \\
& & \\
& & & \\
\hline
\end{tabular}

Table no 3- (18) Table showing ingredients of Vaman karma with their properties

\begin{tabular}{|c|l|l|c|l|}
\hline Sr. No & Name of Ingredients & \multicolumn{1}{|c|}{ Latin name } & Dose & \multicolumn{1}{|c|}{ Properties } \\
\hline 1 & Madanphala Churna & Randia dumetorum & $3 \mathrm{gm}$ & Vamanopag, \\
\hline 2 & Vacha Churna & Acorus calamus & $5 \mathrm{gm}$ & Vamanopag, \\
\hline 3 & Saindhav Lavan & Rock salt & $5 \mathrm{gm}$ & Abhishyandi, Shodhak \\
\hline 4 & Honey & -- & $25 \mathrm{ml}$ & Abhishyandi, Yogavahi \\
\hline 5 & Milk & -- & $2500 \mathrm{ml}$ & Vamanopag \\
\hline 6 & Yashtimadhu phant & Glycyrrhiza glabra & $1000 \mathrm{ml}$ & Vamnopag \\
\hline
\end{tabular}


Table no 4- (14) Showing ingredients of Vaman karma with their properties

\begin{tabular}{|l|l|l|c|c|c|}
\hline Sr.no & & Grade & $\begin{array}{l}\text { Erythema } \\
\text { (redness), }\end{array}$ & $\begin{array}{l}\text { in duration } \\
\text { (thickness) }\end{array}$ & $\begin{array}{l}\text { Desquamation } \\
\text { (scaling). }\end{array}$ \\
\hline 1 & $0 \%$ of involved area, $<10 \%$ & grade: 0 & 0 & 0 & 0 \\
\hline 2 & $10 \%$ of involved area, & grade: 1 & 1 & 1 & 2 \\
\hline 3 & $10-29 \%$ of involved area & grade: 2 & 2 & 2 & 2 \\
\hline 4 & $30-49 \%$ of involved area & grade: 3 & 2 & 2 & 3 \\
\hline 5 & $50-69 \%$ of involved area, & grade: 4 & 3 & 3 & 3 \\
\hline 6. & $70-89 \%$ of involved area, & grade: 5 & 3 & 3 & 4 \\
\hline 4 & $90-100 \%$ of involved area, & grade: 6 & 4 & 4 & 2 \\
\hline
\end{tabular}

Table no 5: Table showing changes in signs and symptoms during each follow up

\begin{tabular}{|l|l|l|c|c|}
\hline Sr. no & Sign and Symptoms & $\begin{array}{l}\text { Before } \\
\text { treatment }\end{array}$ & $\mathbf{1}^{\text {st }}$ follow up & $\mathbf{2}^{\text {nd }}$ follow up \\
\hline 1 & Erythema (Redness), & 3 & 1 & 1 \\
\hline 2 & Induration (Thickness) & 3 & 3 & 0 \\
\hline 3 & Desquamation (Scaling). & 2 & 1 & 0 \\
\hline 4 & Itching & 3 & 1 & 0 \\
\hline
\end{tabular}

\section{Discussion}

Psoriasis is a Papulo Squamous disorder of the skin, characterized by sharply defined erythematous squamous lesions. They vary in size from pinpoint to large plaques. At time it may manifest as localize or generalized Pustular eruption.

Ekkushtha is accepted as psoriasis because the description and characteristic feature of it are coinciding with description of psoriasis.

Aswedanam - The lesion of this disease are dry \& rough, Mahavastu - Lesions are found all over the body, Matsya Shakalopamam -Well-defined raised macules, papules, erythematic plaques which are covered with silvery scales. Krishna Aruna varna - erythematous lesion. (19)

It is counted as Kshudrakustha hence Kushtahar drugs as well as immunity enhancing drugs can be beneficial for this morbid disease. Such as Panchatikta ghrita guggul \& Panchatikta ghrita as it is explained in Bhaishajya ratnavali, kushta adhyay .and for external application Marichyadi tail also explained. $(15,17)$

Ekakushtha is a Kapha predominant type of Kushtha, and Vamana is indicated for Kapha predominant disease. (20) Vamana shows a significant reduction in the level of malondialdehyde (MDA) which is a free radical \& significant increase in super oxide dismutase (SOD) \& glutathione reductase (GSH) which proves potent action of these two procedures in reducing the oxidative state. Vamana acts on microcellular level, eliminate the toxins from body \& helps in maintaining normal function of body.

It strengthens the immune mechanism and helps in preventing relapse. It is just a bio purification of the body. After Shodhana in Kushta Snehana is indicated hence Shamana Sneha with panchatikta Ghrita is given in after Vamana respectively. After shodhana, vata dosha increases, for increase vata the best treatment is Snehna.(21) Kushtha is raktaprdoshaj vikar mentioned by Acharya Charak, so while treating it specific consideration of rakta dhatu is essential. Yakrita and Pleeha are main site of formation of Rakta Dhatu. (22) Vasa, Nimb, Patola, and Amrita are potent hepatoprotective action. These drugs act on the formation site of the Rakta Dhatu and break the basic pathogenesis of Kushtha. These drugs act as potent Antiproliferative property against the T-cells which plays key role in pathogenesis of psoriasis, also inhibiting kerotinocyte proliferation.

\section{Conclusion}

Psoriasis can be compared with Ekakustha on the basis of symptom complex.

Ekakustha sankledapradhan

and

bahudoshavasthajanya condition with the dominance of kapha and vata dosha.

Itching, erythema, scaling and size of lesion are moderately reduced after Vaman karma.

\section{References:}

1. Caraka Samhita, Sutrasthana Ayurveda Dipika Ayushi, Hindi commentary edited by Vd. Harish Chandra Singh Kushwaha Vol-I 7/21, Varanasi: Chaukhamba Orientalia; 2009. p.251

2. Caraka Samhita, Ayurveda Dipika Ayushi, Hindi commentary edited by Vd. Harish Chandra Singh Kushwaha Vol-II 7/21, Varanasi: Chaukhamba Orientalia; 2009. p.198.

3. Charaka Samhita, Ayurveda Dipika Ayushi, Hindi commentary edited by Vd. Harish Chandra Singh Kushwaha Vol-II 7/21, Varanasi: Chaukhamba Orientalia; 2009. p.198.

4. Charaka Samhita, Ayurveda Dipika Ayushi, Hindi 
commentary edited by Vd. Harish Chandra Singh Kushwaha Vol-II 7/41, Varanasi: Chaukhamba Orientalia; 2009. p.209

5. Charaka Samhita, Drdhabala, Vaidyamanorama Hindi commentary edited by Acharya Vidyadhar Shukla Vol-II 7/42, Varanasi: Chaukhamba Surbharati Prakashan; 2012. p.186

6. Charaka Samhita, Drdhabala, Vaidyamanorama Hindi commentary edited by Acharya Vidyadhar Shukla Vol-I, 13/99, Varanasi: Chaukhamba Surbharati Prakashan; 2009. p.210

7. Charaka Samhita, Drdhabala, Vaidyamanorama Hindi commentary edited by Acharya Vidyadhar Shukla Vol-I, 13/34-35, Varanasi: Chaukhamba Surbharati Prakashan; 2009. p.202

8. Charaka Samhita, Sutrasthana, Ayurveda Dipika Ayushi, Hindi commentary edited by Vd. Harish Chandra Singh Kushwaha Vol-I 13/29-40, Varanasi: Chaukhamba Orientalia; 2014. p.208

9. Charaka Samhita, Sutrasthana, Ayurveda Dipika Ayushi, Hindi commentary edited by Vd. Harish Chandra Singh Kushwaha Vol-I 14/18-19, Varanasi: Chaukhamba Orientalia; 2014. p.223

10. Charaka Samhita, Kalpa Sthana, Ayurveda Dipika Ayushi, Hindi commentary edited by Vd. Harish Chandra Singh Kushwaha Vol-II 1/14, Varanasi: Chaukhamba Orientalia; 2009. p.859

11. Charaka Samhita, Sutrasthana, Ayurveda Dipika Ayushi, Hindi commentary edited by Vd. Harish Chandra Singh Kushwaha Vol-I 15/12, Varanasi: Chaukhamba Orientalia; 2014. p.243

12. Charaka Samhita, Sutrasthana, Ayurveda Dipika Ayushi, Hindi commentary edited by Vd. Harish Chandra Singh Kushwaha Vol-I 4/23, Varanasi: Chaukhamba Orientalia; 2014. p.65
13. Charaka Samhita, Sidhistahna, Ayurveda Dipika Ayushi, Hindi commentary edited by Vd. Harish Chandra Singh Kushwaha Vol-II 1/13-14, Varanasi: Chaukhamba Orientalia; 2009. p.877

14. https://en.wikipedia.org/wiki/ Psoriasis Area and Severity Index

15. Bhaishajya Ratnavali, edited by Bramhashankar Mishra Vol-I edition $1^{\text {st }}, 1 / 19$, New Delhi: Chaukhamba Sanskrit Bhavan; 2006. p.71

16. Bhaishajya Ratnavali, edited by Bramhashankar Mishra Vol-III edition $1^{\text {st }}, 54 / 233-236$, New Delhi: Chaukhamba Sanskrit Bhavan; 2006. p.77

17. Bhaishajya Ratnavali, edited by Bramhashankar Mishra Vol-III edition $1^{\text {st }}$, 91/301-302, New Delhi: Chaukhamba Sanskrit Bhavan; 2006. p.91

18. Drugs useful in Panchakarma Therapy edited by Dr. K. Nishteswar \& Dr. R. Vidyanath Varanasi: Chaukhamba Orientalia; 2006. p. 30-38

19. Charaka Samhita, Drdhabala, Vaidyamanorama Hindi commentary edited by Acharya Vidyadhar Shukla Vol-II 7/21, Varanasi: Chaukhamba Surbharati Prakashan; 2012. p.184

20. Charaka Samhita, Drdhabala, Vaidyamanorama Hindi commentary edited by Acharya Vidyadhar Shukla Vol-II 7/31, Varanasi: Chaukhamba Surbharati Prakashan; 2012. p.185

21. Charaka Samhita, Drdhabala, Vaidyamanorama Hindi commentary edited by Acharya Vidyadhar Shukla Vol-II 7/42, Varanasi: Chaukhamba Surbharati Prakashan; 2012. p.186

22. Charaka Samhita, Vimanasthana, Drdhabala, Vaidyamanorama Hindi commentary edited by Acharya Vidyadhar Shukla Vol-I 7/4, Varanasi: Chaukhamba Surbharati Prakashan; 2012. p.588

\section{Before Vamana}

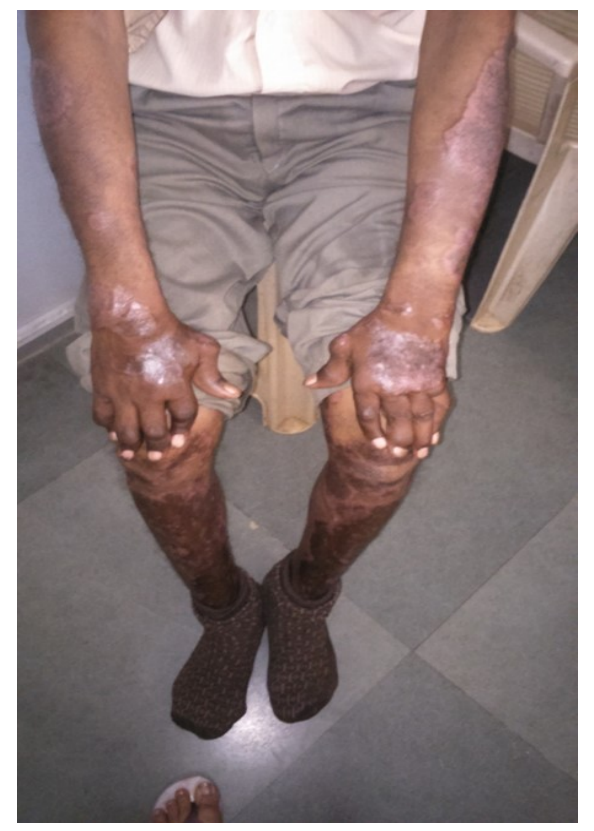

After Vamana

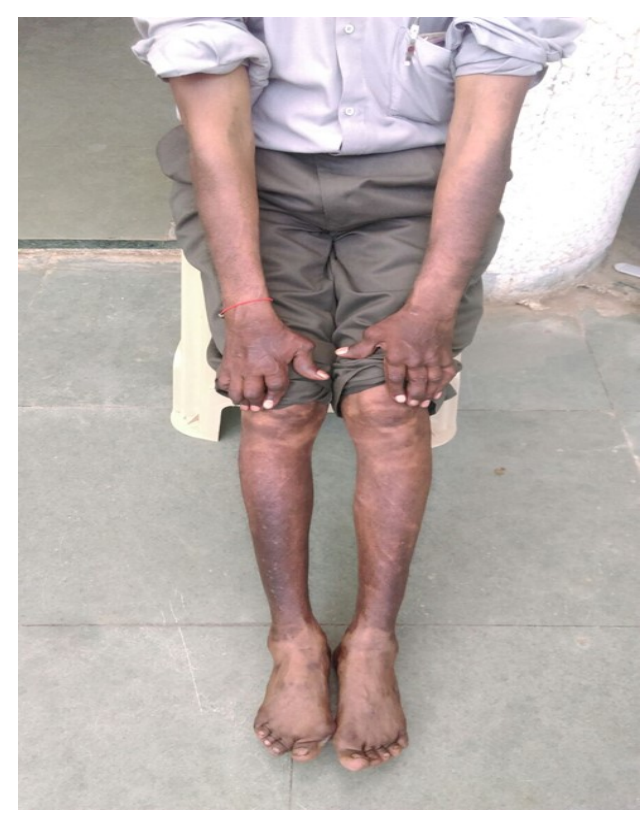

